\title{
Revolution And The Whip Of Reaction: Technicians Of Power And The Dialectic Of Radicalisation
}

Marc Mulholland ${ }^{1}$

\begin{abstract}
This article argues that sociologically informed studies of revolution tend to underestimate the importance of counter-revolution and 'reaction' in generating radicalisation. Revolutions are inherently political. Most accounts recognise this, but emphasise the executive organs of state - such as monarch, cabinet or ministers - at the expense of the intermediary 'technicians of power'. Revolutions, however, typically seek to refashion an entire technocracy of power, and in so doing struggle against embedded and powerful sites of reaction. Central to the dynamic of revolution is the 'purge' of the technocracy of power. As governing structures are not easily transformed at a stroke, revolutions may be seen as punctuating long processes of struggle. Historically, the governing apparatus has been most effectively revolutionised under conditions of military occupation. The thesis is illustrated here by a narrative of revolution in Europe from the English Civil War to the Liberation of the 1940s, with a coda on '68.
\end{abstract}

In his History of the Russian Revolution, Leon Trotsky remarked that "a revolution needs from time to time the whip of the counter-revolution" to provide "a powerful impetus to the radicalization of the masses". ${ }^{2}$ Trotsky was dimly recalling from memory something said by Karl Marx. This, we can presume, was Marx's observation in his 1849 journalism, later collected as The class struggles in France, that the revolution makes progress "not by its immediate tragi-comic achievements but, on the contrary, by the creation of a powerful, united counter-revolution, by the creation of an opponent". It is only when confronted with counter-revolution that those who overthrow a regime are "ripened into a really revolutionary party." ${ }^{3}$ It is the whip of reaction that spurs on revolution.

As a thesis this is clear enough. Revolutions are made, that is to say reform accelerates into rupture, only under the immediate pressure of counter-revolution. It is a thesis, however, that 
has been understated in the voluminous social science literature on revolution. When the 'natural history of revolution' school emerged in the interwar years, counter-revolution was given little attention. ${ }^{4}$ It is true that conservatives were often presented as having an important role at the outset of revolution, even inadvertently launching it by their criticisms of the state. But they were quickly side-lined once attention turned to the crisis of state and the radicalisation of the revolutionaries. Only in the last phase of revolution, the reimposition of stability, might counter-revolution again come back into view, and then often as a new systemic shock, a revolution in itself. ${ }^{5}$ Crane Brinton, briefly, did make the very important observation that revolutions radicalise partly because of a struggle to master the "machinery" of government. ${ }^{6}$ But the idea of 'reaction', of ongoing and threatening resistance to reform, was not given its due in the revolutionary process itself.

In the 1960 s, the interaction of revolution and counter-revolution came more sharply into focus. Charles Tilly saw revolution as a kind of centrifugal process in which the forces of counter-revolution are assembled from the varied social strata thrown off from the spinning gyre at the heart of the revolutionary process. He called this 'schismogenisis', a term borrowed from anthropology, meaning "the increasing polarisation of the norms of two groups as a result of their interaction". ${ }^{7}$ Such insights have given rise to the "contentious politics' paradigm in which extremes feed one off the other. ${ }^{8}$ This dialectic has been usefully applied. Arno Mayer, taking as his examples the French and Russian revolutions, has written an important book on how "violence and terror were both cause and effect of the dialectic of revolution and counter-revolution". ${ }^{9}$ For Mayer, as for other analysts, revolution and counterrevolution are polarising antipodes slugging it out in an attempt to grab at the levers of state power. ${ }^{10}$

Recent theorists of revolution rightly posit the phenomenon in terms of process rather than simple event. The first phase of revolution, as Jack Goldstone puts it, is "state breakdown". This is followed by radicalisation in response to counter-revolutionary threats to the new regime, often supported by foreign powers. ${ }^{11}$ For Goldstone, "state breakdown provides opportunities for both revolution and counter-revolution" because the apparatus of power thus weakened is easily captured by ruthless actors. ${ }^{12}$ This focus on the 'weakness' of governing power may be misleading, however. While the state - if understood as the means and personnel of governance - is typically dislocated it nonetheless and necessarily remains a 
body with will and volition. Its power is not simply left on the streets to be picked up by revolutionaries or counter-revolutionaries. ${ }^{13}$

Social science analyses of historical revolutions often concentrate upon the destruction of the central executive government, what we might call the regime, without paying sufficient attention to the machinery and personnel of governance extending throughout the state territory. ${ }^{14}$ Laws, rules and regulations comprise the technical machinery of power, but this machine requires skilled operators sufficiently familiar with the technique of practical governance. These skilled operators are the vital intermediary between the executive directors of power on the one hand, and the instruments of power - soldiers, bailiffs, police, office-administrators, propagandists, etc. - on the other. We may call these intermediary strata the technicians of power. ${ }^{15}$ The technicians of power do not design or construct the machinery of political and social administration, but they maintain it and they know how it works and how they like to see it working. Technicians of power are not randomly selected. They are drawn from particular social classes and have their own political predilections and the power to act on them.

The state is central to Theda Skocpol's well-known comparative study of revolution. However, in rightly insisting upon the 'autonomy' of the state, Skocpol effectively depoliticises it. In this, she follows Max Weber who wrote that the exceptional power of bureaucracy is "always available for the one who controls the bureaucratic apparatus." 16 This, it seems to me, elides the difficulty involved in controlling bureaucracy. For Skocpol, who takes Weber as her almost "infallible guide," state bureaucrats are formally rational and attached to effective administration rather than any particular ideology. They seek to submit society to their formal rationality. ${ }^{17}$ This obscures the fact that the technicians of power are necessarily drawn from society. Their idea of effective administration is not universal, floating above social norms, but rooted in specific socio-ideological milieux. The state is depicted by Skocpol as a mechanism, with its own momentum power to be sure, but liable to be transferred from the hands of the executive authority in the first wave of revolution, and then repurposed by the victorious revolutionaries. ${ }^{18}$ But the state bureaucracy is not a tool easily passed from hand to hand. It is a body of people drawn from particular sections of society. In times of revolution, so far as the new political elites are concerned, the technicians of power are likely to be drawn from a tainted recruitment pool. The personnel of governance have to be coerced, reformed, and refreshed with new recruits in tune with the revolutionary 
project. This is a disruptive imperative. Revolutionaries are forced to confront the necessity of forcefully interrupting the work of the bureaucracy in order to radically refashion that bureaucracy.

This points to the thoroughgoing nature of revolution. A regime might be decapitated, but its servants throughout the land cannot be so easily removed. Revolution cannot scatter its opponents at one blow. This is perfectly understandable once we appreciate that the structures of established governance run deep through society, and resist easy transformation. Michael Mann has made the useful distinction between executive 'despotic power' and governing 'infrastructural power'. He defines infrastructural power as "the institutional capacity of the central state... to penetrate its territories and logistically implement decisions." It is a "twoway street" between the government executive and society. ${ }^{19}$ This is conceptually useful but the problem with Mann's definition is that infrastructural power is presented as a conduit rather than a body of people with their own attitudes, interests and agency. Seeing the governing nexus as simply a conduit between state and society has encouraged theorists of revolution to conceptualise infrastructural power as a channel to be captured or created by revolutionaries, ${ }^{20}$ rather than an arena of struggle between revolution and reaction. The term 'reaction' dates from the French Revolution, and from the outset implied resistance to radical reform situated in the power technocracy and amenable only to mass popular intimidation. Revolutionaries coined the term réactionnaires (reactionaries) as a label for those who would throw progress back if only the pressure of the popular crowd upon them was diminished. "It is incredible how many of the officials ... are reactionary in their politics," Madam Roland wrote. ${ }^{21}$ A principle dynamic of revolution and counter-revolution is the purge of the governing apparatus.

\section{II}

The technocracy of power was never simply a tool in the hands of executive power. The development of the early modern state can be understood as an unremitting struggle by Royal executives to control recalcitrant, self-willed technicians of power. The mediaeval governing nexus ran along overlapping lines. The King exercised a public authority over the people and a personal and bilateral relationship with his noble vassals. The landlord in turn wielded a manorial power over his labourers and tenants. The clergy kept the only existing citizenship 
records and supervised such welfare structures as existed. In the towns and cities merchant guilds and patrician elites were often self-governing. This was a complex overlapping structure, only weakly controlled by roving royal agents (for example the bailli in France).

In early modern Europe, state authority was exercised over the King's subjects chiefly through the judicial system, which included widely defined police functions. This looks like a professionalisation of state administration. In almost all countries, the Royal Courts of Justice were composed of professional judges trained in the law. Only in Poland and Hungary were the judges directly elected by an assembly of all the nobles in the relevant district. Most countries, moreover, had a special tribunal under central control over and above the regular machinery of government - in England the Privy Council sitting as Star Chamber. It was a labour of Sisyphus, however, to impose central control on the technicians of power. Royal officials tended to become independent of their nominal directors. Their positions were profit-yielding and personally-owned private properties. Offices, indeed, were formally sold as property in 'absolutist' France.

In England it was the chief landowners of each region who enforced royal authority in a system known as 'self-government'. England retained the custom of having notables as judges, who served without pay and did not study law. There were 1,738 of these justices of the peace in the year $1580 .{ }^{22}$ Central government, therefore, "depended for its execution on the voluntary co-operation of a hierarchy of part-time, unpaid officials". ${ }^{23}$ In France it was the rich bourgeoisie who perform these functions, meaning virtual autonomy for the bourgeoisie of the towns. The executive power, with absolutist pretensions, sent out emissaries removable at will - the intendants of justice, police and finance - to impose its decisions. But under Louis XIV there were only thirty-four intendants in the whole realm. ${ }^{24}$ These, moreover, were chosen from among the lawyers already possessing office. ${ }^{25}$ In other continental states there were even fewer such agents appointed and removable by the Prince.

Thomas Ertman has argued that by the $18^{\text {th }}$ century the governing administration in Europe was substantially autonomous where its personnel held their positions as a form of private property. ${ }^{26}$ In early Modern Spain, the Scandinavian kingdoms and the territories of the German princes, the governing apparatus remained less differentiated, and in theory at least the power of Royal officials was unchallenged. These agents of central power, however, were invariably assisted by lawyers or local persons. Continental absolutist sovereigns might claim that governance was entirely in their hands, but in reality they had to work with 
complex governing structures intertwined with powerful social interests. Professor Christian Jacob Kraus, of the University of Königsberg, wrote at the end of the seventeenth century that "The Prussian state, far from being an unlimited monarchy, is but a thinly veiled aristocracy. The aristocracy rules the country in thinly disguised form as a bureaucracy." 27 This was typical. Such formidable technocracies of power could not be merely passive instruments in the hands of the executive.

In the $19^{\text {th }}$ century, to be sure, there was a considerable expansion in the state bureaucracy organised and paid by the regime. But discontinuity with early modern forms of governance should not be exaggerated. Conservative elites particularly appreciated the importance of 'intermediate government', as Eugene and Pauline Anderson call it: roughly county-level administration "sufficiently close to the people to enable the nobility to maintain contact with the masses and to wield effective authority over regional affairs ... [yet] far enough away from the people for its leaders to be carefully selected and yet not isolated." 28 Until well into the $19^{\text {th }}$ century, for most countries, central government was helpless without the mostly unpaid administrative services of local elites acting as the technicians of power.

In the second half of the century a permanent body of professional officials appointed and paid for by the national government became standard. Even in England, where central government employed few other than financial agents, a substantial class of officials in the service of local authorities and municipal bodies grew up. This was Max Weber's famous 'bureaucracy'. Weber argued that industrial society saw the triumph of modern bureaucratic government. As he pointed out, "once it is fully established, bureaucracy is among those social structures which are the hardest to destroy. ... if the official stops working, or if his work is forcefully interrupted, chaos results, and it is difficult to improvise replacements from among the governed who are fit to master such chaos." 29 It must be remembered that modern bureaucracy itself came from a particular milieu, bourgeois and in its upper reaches aristocratic. State personnel, as Göran Therborn points out, were (and are) generally representative of the bourgeoisie, with 80 to $95 \%$ of the higher civil bureaucracy having a non-working class background. ${ }^{30}$ In the late $19^{\text {th }}$ and early $20^{\text {th }}$ century, access even to local positions of governance was socially restricted. It required an education available to only a very small percentage of the population. Even in those countries with the most advanced systems of education - Great Britain, France, Germany - only about 3 to $4 \%$ of those receiving elementary instruction on the eve of the First World War went on to secondary 
school. ${ }^{31}$ The personnel of the governing apparatus came from a very select pool, possessing independent resources of cultural and social capital, and could only with difficulty be directed by the executive power. Analyses of revolution which concentrate only on executive government occlude the tremendous inertial force of the power technocracy. ${ }^{32}$

III

Revolutions - or at any rate 'great revolutions' - are thought of as having profound social consequences with class structural effects. This is what usually demarcates them from coups or simple replacement of heads of state. There is much to be said for this distinction, and revisionist enthusiasms notwithstanding most great revolutions have important class-based drivers and effects. ${ }^{33}$ However, social change is usually a long run process and not easily connected to the ravaging turmoil characteristic of a revolutionary process. A medium range optic may be of use here, interacting with rather than replacing due attention to long-term social change. Revolutions develop when a more limited shuffling of ministers and flurry of ordinances prove inadequate to the social reformers' task of political renovation. Reform is intended to make the political structure adequate to changing social conditions and pressures arising from international relations. As difficulties inhibiting reform accumulate, William $\mathrm{H}$. Sewell suggests, a point of "rupture" may be reached. In this case reformers contemplate radical measures. This in turn usually generates determined resistance. The rupture is normally "neutralised and reabsorbed into the pre-existing structures". ${ }^{34}$ Sometimes, if the old dispensation is self-evidently uncompetitive in the international order, the ruling apparatus will negotiate structural change, a kind of redundancy package for superannuated elites. ${ }^{35}$ But sometimes the rupture escalates into a revolutionary struggle. ${ }^{36}$ The means employed will be drastic in proportion to the thoroughgoing ambition of the ends aimed at; so it is true that 'great revolutions' are profoundly structural. However, it is the purging of the capillaries of the old regime that really throws the body politic into violent fever. Reformers may with dispatch overthrow an unpopular government, but then find themselves seeking the transformation of intractable mechanisms of governing power permeating society, and in so doing they become revolutionaries, or more likely are replaced by those with a revolutionary will. 
In general, revolutions are thought of as 'punctual' events, as Perry Anderson puts it: concentrated bursts of turmoil. ${ }^{37}$ This delimitation is useful in so far as it draws attention to acute periods of contestation for power. ${ }^{38}$ However, once we appreciate the resources of reaction as formidable and embedded in structures of governance that cannot simply be closed down, we may begin to appreciate that revolution is unlikely to capture the trenches of state power in one rush. We see it as a prolonged struggle that will fall into truce but is ever likely to spring up again until the trench-complex of governmental power has been secured one way or another. In this sense, it is surely legitimate to consider revolutions as crisis moments in an epochal contestation stretching over time in a great arc: a process of 'punctuated equilibrium'. ${ }^{39}$ Revolutions are not quite like earthquakes, in which long-term seismic pressures suddenly erupt into a dramatic shift in the social landscape. ${ }^{40}$ Rather, revolutions are recurrent battles over the same field, the nexus of governance.

No doubt, in the course of long-run contestation, certain revolutionary mythologies develop their own motive power. Eric Selbin rightly observes persistent and periodically erupting oppositional cultures. ${ }^{41}$ Selbin draws attention to the historicist narratives that inspire voluntarist action, so that revolutionaries come ready-made for times of crisis. Even revolutionary stories, however, over time may become safely institutionalised. Evidence for this can be found in the long ruling and impeccably centrist Partido Revolucionario Institucional of Mexico, for example, or the tricoleur and Bastille Day of the socially conservative French Third Republic. We do well to remember that even the Bolsheviks failed to anticipate the extremities of 'proletarian dictatorship' before 1917, and until the revolution broke out their concrete strategy saw no further than a radically democratic government dominated by worker and peasant parties presiding over a fundamentally capitalist society. ${ }^{42}$ In times of equilibrium, past revolutionary heroes may be celebrated by public figures but action modelled on their ruthless determination is far outside the politics of the acceptable. In times of revolution, in contrast, reformists despair of moderation, and seek to use drastic measures to secure and remodel the technocracy of power. It is the very intensity of revolutionary crises that concretises the will to revolutionary action. Revolutionism is more of a phenomenon, a reaction to crisis, than it is an idea.

If the technocrats of power are the sinews of counter-revolution, they are also often the origins of the overthrow of the regime. Any regime is wise to keep a close eye on its junior officers, educators, impatient officials, and overeducated aspirants to bureaucratic 
office, all of them notorious as potential leaders of revolutionary crowds and conspiracies. ${ }^{43}$ Klemens von Metterrnich, Chancellor of Austria between 1815 and 1848, and the leading anti-revolutionary statesman of Europe, identified dangerous constitutional ideas as predominant amongst the "the middle classes ... capitalists ... state officials, literary men, lawyers, and the persons in charge of public education." ${ }^{44}$ Revolutions often begin with attempts at reform from within the technocracy of power itself, even at its senior levels, before radicalising beyond their control. The process of revolution is itself a differentiation of revolution and counter-revolution. Revolution and counter-revolution should be seen as conflicts over the demands and ambitions of governance. The very intimacy of the struggle, taking place over and within the technocracy of power, does much to explain the violent trauma characteristic of great revolutions.

In considering revolution we must always bear in mind the crucial importance of the technicians of power - both formal government appointees and those 'captains' of industry, land and journalism who were dispensers of informal but nonetheless coercive social power. These strata were drawn from a particular privileged milieu and resistant to any radical change. Reactionary opposition to revolutionary change characterise the technicians of power, but their inclination to resist utopian schemes of counter-revolutionary restoration is hardly less marked. The governing apparatus is not amenable to easy manipulation. It is a central battleground in the struggle between radical reform and reaction. To reduce a recalcitrant technocracy of power to discipline may ultimately require revolutionary measures. Rarely is this carried out in a clean sweep, and revolutionary crises characteristically punctuate dynamic equilibria in a succession of purge convulsions. To illustrate these points, I shall examine the long struggle towards democratisation in western and central Europe over some 300 years. I shall contend that this great arc of pan-European democratisation was decisively impelled by crises points of revolution.

IV

The English Civil Wars of the 1640s have long been seen in Whiggish history as a moment in the emergence of a constitutional modernity in which the regime is contained by a representative assembly and civil society is permitted legal latitude to express itself politically. Revisionism has complicated this picture no doubt, but at any rate the 
consolidation of English constitutionalism and capital accumulation was unquestionably a key precursor to the diffusion of limited representative government, civil and political liberty, and capitalism through the Western world over many decades reaching far into the $20^{\text {th }}$ century. ${ }^{45}$

The dialectic of revolution and counter-revolution is appreciably at work in the English case. In the 1830s, Thomas Wentworth, Earl of Stratford, had made much headway in centralising royal power in the kingdom of Ireland, a dire warning to the substantially selfgoverning gentry of England. William Laud, Archbishop of Canterbury, was leading a drive to impose top-down power over the apparatus of the Church of England itself. Charles I was securing resources for an incremental building of royal absolutism through the unparliamentary collection of ship money. When the position of Charles I was suddenly undermined by the Scottish invasion of 1640 , Parliamentarians showed remarkable unanimity in their ambition to radically limit the power of the Crown. Parliament secured the imprisonment of Laud and execution of Strafford in 1641. Strafford's execution was a response to the discovery of a plot among the officers of the Royal Army at York to march on London and dissolve Parliament. ${ }^{46}$

Parliament wanted a kind of constitutional monarchy based upon their understanding of traditional English governance. Charles was to remain as king, but without many of the attributes of kingship as then understood. This, surely, was a regime overthrown. But the King's resources for counter-revolution were far from exhausted. Those who supported Parliament lived in terror of Charles repudiating concessions made under duress. In particular it was feared that he would turn against Parliament the army that had been raised to crush the Irish rebellion of 1641. It was fear of counter-revolution that led the reformers to make a truly revolutionary demand: that the army fall under the direction of Parliament rather than the Crown. ${ }^{47}$ Charles at least was under no illusion as to what this would mean:

Next to religion, the power of the sword is the truest judge and greatest support of sovereignty, which is unknown to none (as it may be religion is to some). Whosoever will persuade you to part with it does but in a civil way desire you to be no king; reward and punishment, which are the inseparable effects of regal power, necessarily depending upon it. ${ }^{48}$ 
Parliament's determination to hobble the crown was backed up by the London crowd. Characteristically, the plebeian population of the capital city was fearful of counterrevolutionary vengeance. John Pym's exploitation of popular militancy against the Crown, in turn, galvanised the resources of counter-revolution. The willingness of Parliament's leaders to use the pressure of the 'mob' against the Crown's supporters alienated great swathes of moderate reformers. The unanimity of Parliament shattered. In 1642 that the King was able to build a party, "motivated more by reaction against Parliament than by any enthusiasm for him," as Blair Worden puts it. ${ }^{49}$ Across the country, nobles and gentry feared that Parliament was radicalising out-of-control, and they rallied to the standard of the Crown in the hope of stemming the tide. The arming of counter-revolution in turn drove the parliamentarians to outright rebellion.

Long years of civil war shifted the leadership of Parliament to increasingly radical and ruthless warriors of God. The Presbyterians, favouring in church and state governance a structure inclusive of all the social elites, were increasingly challenged by the Independents, who inclined towards self-organisation of the yeoman property owners. Parliament defeated the King only to come into collision with its own army which had fallen under the control of the Independents. In 1648 the army struck and purged Parliament. Charles I was ultimately executed, in 1649, as a "man of blood" treasonous to his own people, and a Commonwealth was established. The Commonwealth, however, lacked wide support, and was superseded in 1653 by the Protectorate which attempted to rest upon the power of the army and administration. As was made clear by the attempted rule through the Major-Generals (August 1655-January 1657) any attempt to bypass the structures of governance embodied in the provincial and local gentry could be no more than a temporary expedient. The administration of the country refused effective cooperation. ${ }^{50}$ Support for the Cromwellian regime sapped away. Reaction was both successful and popular when the interregnum came to an end, and Charles II was restored to the throne in 1660.

Nonetheless, the very same structure of governance - the technocracy of power - was not anxious to see counter-revolution itself become destructive of established rights and norms as they enjoyed them. There was wide support for a 'mixed constitution', not for Stuart absolutism. Charles II excluded the Presbyterians from the nexus of governance by requiring an oath of adhesion to the established church for those performing public functions. Many gentlemen, loath to lose their influence in the nexus of governance, returned to the 
Anglican Church. Parliament in response compelled Charles to exclude the Catholics from public office. Charles tried to maintain some kind of rough equilibrium, but his successor, James II, was a far more belligerent monarch. He alienated even the Tories who were attached to the established church. James was intent on purging the state apparatus, appointed Catholics to high offices of state, and resolved, as he said, "to make the justices of the peace in the counties Catholic". ${ }^{51}$ During his reign, he dismissed substantial numbers lieutenants, deputy lieutenants and justices of the peace. Had he acquired a Catholic Irish army to overawe the nation perhaps he may have restructured the sinews of governance from above. But if the inertia of administration frustrated revolution, it also frustrated radical counterrevolution. James succeeded only in irritating the technicians of power, the 'unacknowledged Republic' of officeholders. ${ }^{52}$ As it was, excluding Catholics, elements of the armed forces and those personally appointed by James, the governing class was nearly unanimous in welcoming the army of William of Orange and the Glorious Revolution of 1688.

Of course, there had been near unanimity in opposition to Charles I also, at first. But in 1688, despite the large number who feared the consequences of formally excluding James II from the throne, reaction could not get a foothold. The intercession of William's foreign army saved the revolution from relying upon the resources of either the existing state or the popular masses for just long enough to equilibrate the forces of revolution and counterrevolution. ${ }^{53}$ The presence of mercenary soldiers and a foreign king allowed time and space for the consolidation of the revolution. ${ }^{54}$ This was by no means an entirely consensual process. Catholic Ireland, considered to be ineradicably reactionary, was thoroughly conquered and locked under a regime of penal legislation. At length, the governing apparatus in England was purged and reconstructed. From 1714, when George I threw in his lot in with the Whig aristocracy, leading Tories were excluded from political office and the higher posts in the army and church. Tory merchants and financers were excluded from public contracts. Tory magistrates were dismissed wholesale. The governing apparatus liberally dispensed bribery to secure a Whig electoral victory in $1715 .{ }^{55}$ Nonetheless, the squirearchy, which provided the sinews of local government, remained broadly Tory even during the long Whig hegemony at national level.

As the threat of Jacobite counter-revolution rapidly diminished, the Tories consolidated as a loyal opposition and government-in-waiting, sufficient to prevent the crystallisation of a technocracy of power owned by one faction. The revolution survived and 
prospered. The advantages of constitutionalism became increasingly evident and a matter of jealous attention for overseas competitors: a civil society free to accumulate wealth, a Parliament able to make its will effective, a regime enjoying steady tax revenue, and thus ample credit guaranteed by the representatives of the governing classes. ${ }^{56}$ The Glorious Revolution settlement in England had emerged through a contestation and symbiosis of revolution and reaction.

\section{V}

The Crown in France appreciated that aspects of British governments might usefully be emulated, and so did the governing elites themselves. The French Revolution began with the crown offering the nobility consultation in return for economic and administrative reform. The nobility demanded an extension of representation and the convening of an Estates General. The first and second estates were clergy and nobility, central to ancien régime administration. Of the 580 deputies elected to represent the third estate, the great majority were technicians of power: $43 \%$ held venal government offices, and another $35 \%$ were lawyers. Only $30 \%$ came from trade and industry. Called to Paris, these representatives of France's governing elites demanded wholesale reform and the institution of constitutionalism and a limited monarchy. The crowd of the capital city played a key role in tearing down the Bastille (14 July 1789), securing Paris against army intervention. The revolt of the peasantry la Grande Peur - battered the resources of counter-revolution throughout the country.

There was a serious attempt by the National Assembly to refashion the apparatus of government. The nation was divided into uniform departments. Those exercising public functions were elected by the inhabitants of the region in which they operated. The result was a system of elective local autonomy. Even priests were to be elected. As in England, however, those who had overthrown the real power of the King wished to keep his person at the centre of the new constitutional setup. In this way, they hoped, the vast governing apparatus, and in particular the army, could be reassured that they would not fall victim to wholesale restructuring or popular fury. But this attempt to enfold the resources of counterrevolution rather than expel them, though prudent in many respects, was pregnant with danger. Louis XVI was the hapless focal-point for numerous counter-revolutionary cabals 
permeating the governing structures of the country. Terrified by the prospect of the technicians of power turning against them, reformers became revolutionaries.

Louis's flight to Varennes (20/21 June 1791), in which he was intercepted and captured on his way to a rendezvous with émigré counter-revolutionaries, made quite clear that disaster was only one act of treason away. The plebeian sans-culottes of Paris identified traitors everywhere in the governance of France, with the king at its head. The Parisian sections petitioned the National Assembly on 3 August 1791,

Parricidal Frenchmen, led by the brothers, relatives and allies of the King, prepare to murder their country. ... It is the head of the executive power who is the first link in the counter-revolutionary chain. ... He has separated his interests from the nation. We, too, separate them. For as long as we have a king like this, liberty cannot take firm root, and we wish to remain free. ${ }^{57}$

In an attempt to confront counter-revolution with the starkest possible consequences of its disloyalty, the Gironde party brought France into war with Austria and Prussia. This was to test the loyalty of the Crown and to expose the reactionaries of the power technocracy. "We have need of treachery on a grand scale," Brissot told the Jacobin Club on 31 December 1791, "for strong doses of poison still remain in the body of France, and strong measures are necessary to expel them." 58 Just over a year later, the revolutionary Convention announced that the execution of Louis XVI to the nation, and called for "the most active surveillance of the domestic enemies of liberty." 59

The disasters of war at first only served to multiply the opportunities and motives for treachery to the revolution. In April 1793, General Dumouriez defected to the invading enemy. The radicals of the revolution, the Jacobin club, on 13 April demanded a revolutionary catharsis to destroy and reconstitute the power technocracy irredeemably infected with counter-revolution: "Let all equally unite to demand that the thunder of decrees of accusation be loosed against treacherous generals, prevaricating ministers, functionaries, and on all the faithless agents of the government. This is our best means of defence: let us defeat the traitors and tyrants." 60 This was the preliminary to the purging, on 31-2 June, of the National Convention of its republican moderates by 20,000 armed sans-culottes. The subsequent revolutionary Committee of Public safety set out to purge the governing apparatus nationwide, empowering représentants en mission to use Terror to intimidate the provinces. 
Nonetheless, experienced administrators, usually inherited from the old regime and more likely to be pragmatic than revolutionary, could not simply be dismissed. They were intimidated by revolutionaries, but administrators in turn would tame the revolutionaries. Years ago, Crane Brinton noticed how the Jacobins devolved from zealous revolutionaries into "auxiliary administrative bodies" to carry out the less responsible duties of governance. ${ }^{61}$ Indeed, as Howard G. Brown notes, after the shock of tumult, rural communities led by their notables "were in important ways both stronger and more autarkic than before." 62 As the invasion-scare faded, the 'mob' of Paris was demobilised, and the governing elites recomposed themselves and rolled back radicalism. Centralised government attempted to take all power into its own hands and delegated it to a single agent in every administrative area the prefect or the mayor (maire) appointed and remunerated by the central government. No elective public authority survived. Governmental agents from now on were mostly strangers to the district in which they worked. They had been sufficiently battered, however, that army rule - as in England in the 1640s and 50s - was near enough inevitable. Napoleon Bonaparte found a civil society prostrate and exhausted, and battened upon it, organising it for permanent war. Bonaparte's final defeat in 1815, and the restoration of the Bourbon monarchy, came for many as a relief.

That the French Revolution was still not complete is now a historical truism. ${ }^{63}$ It is significant that the governing strata under a different name, the notables, survived well into the post-1870 Third Republic. In particular, high civil servants, defined as conseillers d'État, were a semi-hereditary elite, typically married into the landowning and business classes. ${ }^{64}$ What is striking in the history of late $18^{\text {th }}$ and $19^{\text {th }}$-century France is the continual purging, restoration and re-purging of the technicians of power in the country. The restored French monarchy dismissed office holders who dared to oppose a stringent press law in 1824. Ultraconservatives and legitimatists were purged after the 1830 revolution. In the 1848 revolution radicals fretted that in the countryside "all the officials have retained the positions they held under the former regime. The population does not understand how, in a Republic, you can possibly keep leaders who are incapable of rendering good service." ${ }^{65}$ Republicans were appointed to the administration, but to the delight of conservatives they were thoroughly purged out again by President Louis Napoleon. ${ }^{66}$ In the French Second Empire, Napoleon III required servants of the state to openly support in elections the government mandated official candidate: "every local official, from the mayor to the roadman ... [was to] to praise the official candidate and criticise his opponents." 67 When the Empire fell after defeat at the 
hands of Prussia in 1870, the new Prime Minister Gambetta declared ineligible for election all persons who had been officials, deputies or official candidates under the Empire. Nonetheless, royalists won the subsequent election and purged all offices held at pleasure (prefects and sub-prefects, commissioners, inferior judges, and district attorneys). A secret report prepared for Gambetta in 1876-8 found that 70 per cent of army officers were 'conservatives', 'reactionaries', 'Bonapartists', or 'Royalists'. ${ }^{68}$ In 1882, with Republicans back in the saddle, the law that made judges irremovable - itself an attempt to politically neutralise the administration - was suspended for six months to allow the government to retire Conservative magistrates. ${ }^{69}$ The story of the long French Revolution pivots on a struggle to purge and reconstitute the governing administration.

\section{VI}

When Europe-wide Revolution did break out in 1848, it was widely acknowledged as centring on "the right of the middle-classes to a share in their own Government." 70 The forces of resistance, well remembering the trauma of the great revolution in France, withstood the gale. Crucially for the fate of central Europe, the state apparatus of the Austrian Empire remained organisationally and ideological intact. Its military machine under the command of Radetzky and Jellaćić, disproportionately comprising Slavic peasant soldiers little enamoured of urban ideologues, easily crushed the revolutionary cities. The revolutionaries themselves, desirous of maintaining the state apparatus as a bulwark against disintegration, found themselves funding through their parliaments the very forces that would destroy them. ${ }^{71}$ The urban crowd - mostly artisans, apprentices and students - were of more fiery temper, and attempted to disarm and to disorganise the counter-revolutionary state apparatus. In so doing, they only succeeded in alienating those constitutionalist middle classes who feared anarchy. Reflecting on this, Rudolph Stadelmann posits a "law of the radicalisation of extreme groups" operating "to the benefit of reaction" that "drove the entire middle class into the arms of the old powers of order and divided liberalism". ${ }^{72}$

From 1815 the Holy Alliance Conservative states of Europe had relied upon the governing capacity of the aristocracy, gentry and clergy to keep at bay the revolution. In this they had been disappointed. The revolutions broke out, and had to be crushed by state armies and skilful bureaucracies. The lesson was learnt. In the aftermath of 1848 , the executive 
governments of continental European states had a new confidence in themselves, and a new disdain for the pettifogging traditionalism of aristocracy and church. There was, to be sure, no full-scale rupture, but as Alexis de Tocqueville noticed, continental regimes were blithely willing to "supersede the aristocracy by public functionaries". ${ }^{73}$ Prussia, Piedmont-Sardinia and France embarked upon adventurous foreign policies, leading at length to unification of Italy and Germany under regimes that were at least semi-constitutional.

Nonetheless, across Europe technicians of power were still disproportionately drawn from the aristocracy and their hangers-on, and even as administrations were bureaucratised, they enfolded the personnel and much of the ethos of the traditional power technocracy. Though electoral franchises expanded, technicians of power typically remained antagonistic to democratic pressure from below. An oligarchy of upper bourgeoisie and the landed elite congealed, mediated by a 'professional' public service disdainful of the fickle public. This technocracy of power extended beyond the paid servants of the regime. The authority and power of the landowner over his tenants, the capitalist farmer over his labourers, the industrial magnate over his factory district, the professor over his students, and the newspaper proprietor over his readers complemented and intertwined with that of the civil service, judiciary, police and army. This sustained, as Hans-Ulrich Wehler puts it, the "matrix of the authoritarian society". ${ }^{74}$ There were certainly cleavages dividing the technicians of power, but a common habitus of elite respectability ensured a substantial consensus that democracy in the raw must be warded off.

Self-conscious revolutionaries, increasingly operating under the banner of socialism, were certainly aware that the machinery of government represented a formidable obstacle. During 1848 revolutions, Karl Marx saw the power technocracy as the first obstacle to consolidating the revolution. Marx blamed the liberals "for not having acted in a dictatorial manner, for not having immediately smashed up and removed the remains of the old institutions. While ... [they] indulged in constitutional fancies, the defeated party strengthened its positions within the bureaucracy and in the army". ${ }^{75}$ Auguste Blanqui excoriated the revolutionaries of 1848 for having "kept in place the états-majors royalistes, the royalist magistrates, the royalist laws. Treason!"76 Marx and Blanqui envisaged a 'dictatorship of the proletariat', in which organs thrown up by the urban working class would displace the pre-existing technicians of power. Marx and Engels saw in the Paris Commune this dictatorship of the proletariat in action. Only by smashing the state and replacing it with a revolutionary dictatorship might 
the intransigent resistance of 'bourgeois society', with all its resources of governing experience and administrative connections, be overcome. ${ }^{77}$

\section{VII}

The problem of what to do with the forces of reaction embedded in the governing administration remained only theoretical for Marx and Engels, and to a substantial extent for the mass socialist parties that developed in their wake in the years leading up to $1914 .^{78}$ Engels in 1891 had warned August Bebel, the leader of German Social Democracy, that for a socialist government,

the technicians will be our chief enemies; they will deceive and betray us wherever they can and we shall have to use terror against them but shall get cheated all the same. It is what always happened, on a small scale, to the French revolutionaries; even in the ordinary administration they had to leave the subordinate posts, where real work is done, in the possession of old reactionaries who obstructed and paralysed everything.

His hope that socialist parties, in the years of steady electoral growth, would recruit enough young engineers, doctors, lawyers and schoolmasters to create new technicians of power to replace the old was rather forlorn. ${ }^{79}$

The problem of governance became very real in Russia in 1917. After the overthrow of the czarist government in February 1917, the principal issue at stake quickly became that of how the anticipated counter-revolutionary reaction was to be defended against. In the first instance, the revolutionary workers councils - the soviets - kept a watching brief on the technicians of power inherited from czarism. They feared counter-revolutionary conspiracy. Rex A. Wade writes that Russian socialists "had an exaggerated notion of the strength of "the bourgeoisie' and the political right, and an obsessive fear of counter-revolution." 80 Given the experience of the 1905 revolution in Russia, it might well be legitimate to ask whether this fear was indeed quite so exaggerated. ${ }^{81}$

Whatever the case, Lenin's Bolsheviks argued strenuously for a complete displacement of the state apparatus, with workers committees, militias, and soviets taking 
over entirely the job of administration. These arguments were given extraordinary traction by the attempted right-wing Kornilov coup d'état in August 1917, and the blundering if not complicit manoeuvres of the Provisional Government. It is certainly the case that the mass of the urban population favoured some kind of socialist dispensation, but it is far from evident that they thirsted for a leap into the socialist millennium. The mass support lent to Bolsheviks in the urban areas owed less to utopian hopes for social transformation than to a conviction that the only alternative to outright counter-revolution was the establishment of an entirely socialist government willing to take the necessary steps to scotch the reactionary threat. Lenin's emphasis, therefore, was on destroying the armed power of classes hostile to the revolution: "disarming (vanquishing if they resist) the junkers, etc." 82 The Bolsheviks' collective leadership well understood that workers were defensively cautious rather than euphorically millenarian, but they calculated that popular fear of reaction would ensure passive toleration towards a Bolshevik insurrection against the temporising Provisional Government. $^{83}$

It is important to be clear that the Bolsheviks were setting up as a standard for their revolution not the complete nationalisation of the means of production or the immediate elimination of the market, but rather the reconstruction of the state. Lenin made this clear in announcing the new regime:

What is the significance of this revolution? Its significance is, in the first place, that we shall have a Soviet government ... The old state machinery will be smashed into bits and in its place will be created a new machinery of government by the soviet organisations. ${ }^{84}$

The Communists believed that increasing state intervention in the economy was an inexorable process whether under a bourgeois or a proletarian government. The crucial question was the social profile and political loyalty of the technicians of power. ${ }^{85}$ Until about June 1918, the Communists in Russia expected to maintain a mixed economy, under worker direction for the foreseeable future. Massively state-directed 'War Communism' - which was introduced as the economy collapsed - was a civil war makeshift, to supply the Red Army and to smash the social basis of capitalist reaction, rather than a considered program of social transformation. It was, of course, put into reverse and the market allowed to redevelop under the New Economic Policy from 1921. The point here is that the Bolshevik program was one 
of class-war to reconstitute the state apparatus, which they widely defined (not unreasonably) as including the captains of industry and agriculture.

The invitation to the first congress of the Communist International, issued on 24 January 1919, made clear that the Communist aim was to formulate an international strategy for transforming the political regime in the widest sense: "The task of the proletariat now is to seize state power immediately. The seizure of state power means the destruction of the state apparatus of the bourgeoisie and the organization of a new proletarian apparatus of power. ... Its concrete form is given in the system of the Soviets or of similar organs." 86 The "Manifesto to the World', issued by the Comintern on 6 March 1919, stated that the duty of revolutionaries was to hasten the disintegration of the armed forces and to institute direct proletarian class rule. The conquest of political power,

means not merely a change in the personnel of ministries but annihilation of the enemy's machinery of government; disarmament of the bourgeoisie, of the counterrevolutionary officers, of the White Guard; arming of the proletariat, the revolutionary soldiers, the Red Guard of workmen; displacement of all bourgeois judges and organization of all-proletarian courts; elimination of control by reactionary government officials and substitution of new management organs of the proletariat. ${ }^{87}$

It was evident from the Russian experience that the thorough reshaping of the governing nexus could not proceed without provoking widespread resistance and consequently a radicalisation of the revolution. When the Bolsheviks seized power in Russia they very quickly realised that it was no simple thing to side-line the existing technicians of power. They had hoped at the outset that the civil service, army, industry and production in general could be run by its existing managerial caste, but under the direction of the 'dictatorship of the proletariat and poorer peasantry'. Unsurprisingly, however, the Bolshevik insurrection provoked counter-revolutionary resistance. The head of the army had to be replaced. A civil service strike was called, and armed red guards were required even to uncover the keys to bureaus containing key governmental documents. ${ }^{88}$

But the new regime could not do without the services of the old technicians of power. Between 1918 and 1920, almost 50,000 ex-Tsarist officers served in the Red Army. They were disciplined by political commissars and threat of retribution. As head of the Red Army, Trotsky issued an order on 10 September 1918: 
Although the desertion of traitorous officers to the camp of the enemy is becoming less frequent, yet it still goes on. This monstrous crime must be stopped at all costs. The deserters betray the Russian workers and peasants to the Anglo-French and Japanese-American robbers and executioners. Let them know that they are at the same time betraying members of their own families: fathers, mothers, sisters, brothers, wives, and children. The staffs of the armies of the Republic, as well as the regional commissars, are ordered to report by telegraph to Aralov of the Revolutionary War Council the names of all deserting officers with all the necessary information about their families. Aralov, in cooperation with the proper institutions, will take the necessary measures to arrest the families of the deserters and traitors. ${ }^{89}$

The technicians of power, therefore, were disciplined by holding their families hostage. Trotsky, in this regard, was no hard-line outlier - he was criticised by the Communist left for his indulgence of bourgeois officers and professionals in service of the Soviet regime.

The Cheka was established to terrorise those officials who were accused, in a Soviet decree, of attacking the government "on all sides": To fight the internal foe it was necessary to "create an organ ... that would protect the rear of the Red Army and permit the peaceful development of the Soviet form of government." 90 It is in this context that War Communism, and indeed the persistence of strategic state control of the economy thereafter, must be understood. As Trotsky wrote, 'socialisation' of the means of production was a side-effect of the revolutionary conflict:

If the capitalist bourgeoisie consciously and malignantly transforms the disorganization of production into a method of political struggle, with the object of restoring power to itself, the proletariat is obliged to resort to Socialization, independent of whether this is beneficial or otherwise at the given moment. And, once having taken over production, the proletariat is obliged, under the pressure of iron necessity, to learn by its own experience a most difficult art - that of organizing Socialist economy. Having mounted the saddle, the rider is obliged to guide the horse - on the peril of breaking his neck..$^{91}$

It was the pressure of counter-revolution that drove the Bolsheviks to rapid organisation of a radically post-capitalist regime, one which otherwise they had expected would evolve slowly and in an orderly manner. 
In the course of the Civil War, the old administration was indeed shattered and dispersed. No worker administration stably took its place, however. Instead, numerous technicians of power from the old regime were commingled with rough-and-ready party cadres to keep afloat the Communist dictatorship. From the late 1920s, agricultural collectivisation and forced-pace state-led nationalisation set out to destroy the social basis for a putative counter-revolution. Between 1925-6 and 1932 the role of the private sector in the Soviet economy declined from 54 percent to 9 percent. ${ }^{92}$ Deep dyed suspicion of bureaucrats obsessed the regime. It feared that traitors to the revolution were permeating the Communist Party itself. Purging of party and administration ranks became standard practice. As David Priestland writes, “when officials obstructed the centre's campaigns, Moscow intensified the pressure by reverting to the old populist revivalist strategy, using a rhetoric of 'class struggle' to suggest that the bureaucracy had absorbed the undemocratic and inegalitarian attitudes of the old bourgeoisie." ${ }^{93}$ In 1936, this turned into a paroxysm of persecutory violence directed against the technicians of power, both old and new, in the Great Purge.

\section{VIII}

In central and southern Europe revolution was also a reality by 1918. It is important to note that while this "wave of apocalyptic militancy" was socialistic in its ideology it aimed not for the immediate transcendence of capitalism as an economic system but rather envisaged "a vast but vague democratisation," as Charles S Maier puts it. ${ }^{94}$ The left was looking less for "any specifically socialist advance than a further strengthening of Parliamentary democracy, the expansion of workers' rights under the law ... [and the] toughening of civil society

through the enhancement of the public sphere". ${ }^{95}$ Even in Austria, which emerged as an independent state from the collapsed Habsburg Empire, and where the self-identifying Marxist (but non-Communist) left won $40 \%$ of the vote, socialists went into coalition with 'Christian Socials' and pursued a policy of class balance rather than proletarian domination. Their aim was to thoroughly democratise the governing apparatus. A leading Austrian socialist, Julius Braunthal, recalled that when his party, the SPÖ, inherited power in 1918, its priority was "the entire demobilisation of the whole of the Habsburg forces", "for we felt that if units of the Habsburg army were left intact, they could become, under the command of vigorous officers, the nucleus of reactionary resistance to the new Republican regime." Socialist-led workers councils monitored the technicians of power. As Braunthal put it, the 
"non-socialist parties, representing the peasants and the middle classes, had actually lost all power, which had rested hitherto upon the army, the police and the state administration." But the industrial proletariat were pushing "the revolution up to the limits of its strength", threatening to alienate the non-proletarian masses to the point of civil war, and to provoke foreign powers into invasion. ${ }^{96}$ Here we can see an uneasy attempt - though temporarily quite successful - to ride the two tigers of revolution and counter-revolution. But Vienna, the 'red' capital of Austria was surrounded by the deeply hostile 'black' (or catholic) countryside. Once the socialists lost control outside the capital, Vienna was isolated, provoked and starved of funds by the national government. ${ }^{97}$ In 1934, open socialist organisation was crushed in a state organised coup d'état.

The impetus of the revolutionary upsurge at the end of the Great War was democratic with a socialist twist. Germany was the locus classicus. Here the extraordinarily powerful technicians of power, by the end of the war led by a military command unencumbered by responsibility to the civilian regime, suffered a shattering blow to its credibility as it became clear that the war was lost. From the outset, the ambition of the power technocracy, from the General Staff downwards, was to sustain its power behind the protective cover of a civilian legislature and cabinet. The great mass of the urban population, however, was rightly suspicious of a superficial regime-change leaving the reality of power unchanged. There sprang up in November 1918 workers and soldiers' councils seeking to contain and control the political power of the local and municipal government, the police, the officer class of the army, the industrialists, the landed elite, and the civil service. ${ }^{98}$ During November and December 1918, representatives of the workers' councils - the Räte - supervised the technicians of power to prevent them subverting the revolution. ${ }^{99}$ Senior-ranking British officers, asked by London to report, were rather of the opinion that these workers and soldiers councils were the best hope for democracy in the fledging republic. ${ }^{100}$

The socialist SPD government, however, feared that the Räte were a provocation to the counter-revolution, and they doubted their ability to govern against the will of the technicians of power they had inherited. On 10 November 1918, the same day a socialist government was formed in Germany, SPD leader Friedrich Ebert secretly agreed with Wilhelm Groener, Chief of Staff of the German armed forces, that the army would be used for internal policing duties, and that the workers' councils would not be permitted to build up parallel governing structures. The SPD government appealed for civil servants and state 
employees to remain in post, and the Weimar constitution made them irremovable. Despite these concessions, as Richard Evans points out, the higher civil service, which had "long been accustomed to regard itself as the true ruling caste," developed no enthusiasm for the new dispensation. ${ }^{101}$

Radicals - the Sparticists who quickly adhered to the Communist cause - argued for a workers' council-based dictatorship to smash the technicians of reactionary power still effectively running the country. The government, they argued, had made a fatal mistake in leaving the old officers in place:

Had the government abolished the authority of army officers, had it removed the generals from their posts, then these men would not openly hatch counterrevolutionary plots today. ${ }^{102}$

The power technocracy had to be smashed and replaced:

... workers have to replace all the traditional organs of bourgeois class rule. Federal councils, parliaments, and municipal councils must give way to workers' and soldiers' councils. The workers have to occupy all posts, monitor all administrative activities, and adapt the needs of the state to their own class interests and to socialist demands. ${ }^{103}$

Most ranks and file socialists saw in in the Sparticist strategy only the abyss of anarchy, and there was strictly limited support for a revolutionary confrontation with the technicians of power. But most socialists were hopeful that the army could be democratised and the bastions of reaction brought under control. ${ }^{104}$ The Social Democratic ministers, however, hoped to placate the power elites - and did so partly by unleashing bloody repression against radicalism - in the hope that over time the governing structure of the country could be gradually be democratised and won genuinely to the Republic.

It is certainly true that the power technocracy never became Republican in spirit. The neutrality - at best - of the army during the right-wing Kapp Putsch (March 1920) disillusioned even the most purblind of anti-revolutionary Social Democrats. The head of the Reichswehr (army), Hans von Seeckt, informed the government that the army would not act to defend the legally constituted power. SPD leader Noske was shattered: "This night has 
shown me the bankruptcy of my policy. My faith in the officer corps is shattered. It has deserted me." 105 It was a general strike bringing the country to a halt that prevented the movement of putschist troops and saved the Republic. The technicians of power in the state administration, industry and agriculture, nonetheless, remained un-reconciled to democracy and deference to proletarian interests. ${ }^{106}$ The Weimar judiciary was infamous for its favouritism towards right-wing street-fighters and assassins, and the army was dominated by "an officer corps with monarchical convictions", as a chief of the army High Command approvingly put in $1919 .{ }^{107}$

The most democratically minded party - the SPD - was removed by the electorate from government in June 1920 (though they remained the largest single party). In the Prussian state government the SPD remained in office until removed by a presidential decree of dubious legality in 1932. In the interim there is no doubt that the Prussian police were reformed - which showed what might have been done at a Reich level if the SPD had displayed more audacity ${ }^{108}$ - and in terms of democratic ethos the Prussian technicians of power were far in advance of any other governing structure in the country. It is not entirely clear, however, whether even the democratised Prussian police would have defended the constitution if called upon to do so. Across the Reich, the army remained almost entirely immune to democratisation. Ironically, this was partly due to the Allies imposing a limit of 100,000 men on the Germany army, ensuring that only the most militaristic reminded volunteers joined. It was an insuperable problem in Germany and elsewhere that those who were democratically minded, and in particular socialists, were least likely to be attracted to a military career.

The victory of Nazism was not simply due to conservative conspiracy against the Republic; but it was certainly facilitated by it. After Hitler banned the SPD, the party in exile reflected soberly on the experience, concluding that "it was a grave historical error on the part of the German working-class, bewildered as it had been during the war, to take over the structure of the old state without transforming it." ${ }^{109}$ They had learned the bitter lesson that even democratic revolution requires thorough reconstitution of the power technocracy to root out reaction. 
Across Europe, the democratic upsurge which followed the First World War was steadily and sometimes very dramatically rolled back over the next 20 years or so. Only very occasionally was it possible for an insurgent movement to more or less completely replace the pre-existing power technocracy. In Ireland from 1919, the nationalist "revolutionary government gained a wide measure of effective authority in the country", ${ }^{110}$ But this was an exception that proves the rule, for in Ireland the social basis for British loyalism outside Ulster, and the ideology of Catholic anti-democracy throughout the island, had long withered to almost complete attenuation, ground to dust between the regime imported with the Glorious Revolution and democratic nationalist mobilisation. Almost everywhere else in Europe the power technocracy remained in place, evincing a suspicion of democracy at best and turning to authoritarianism when faced with social turmoil and revolutionary subversion.

To be sure, the technicians of power lacked the natural authority they had enjoyed before 1914. In many countries - most dramatically in Italy and Germany - the power technocracy had to lend their support or smooth the way for populist right-wing mass movements. There was never any doubt, however, that the landed elites, industrialists, civil servants, judiciary, army and police were biased against the left, indifferent to democratic values, and willing to indulge the extreme right. The Italian liberal historian, Guglielmo Ferrero, in 1925 bemoaned the political system that allowed Mussolini to come to power:
Although Parliament performed various functions, all of great importance, it was nevertheless not a governing organ. ... the actual direction of public affairs lay elsewhere and descended from above, where was concealed what might be called 'the oligarchy of the elders' - a little group of high officials and influential parliamentarians, all grown old. ... This little group of oldish men was supported ... by the two most solid organs of the state - the monarchy and the bureaucracy. It was this group which, invisible to outside observers, ruled the country and decided all matters of capital importance. ${ }^{111}$

From 1920, employers in Italy financed Fascist gangs to break labour strikes while the judiciary and police stood aside or assisted the Blackshirt gangs. In 1922 the crown invited Mussolini into government. It is now broadly accepted that "Mussolini owed his ascent not to a revolution, but to the assistance of the king, the heads of the armed forces, and most of the 
existing political establishment." 112 Fascism - which expressly celebrated the technicians of power - was a resource for desperate reaction.

The progressive, socialist inflected government of Spain was predictably attacked by a broad-based right-wing coup in 1936. In Spain, as Manuel Tuñón de Lara pointed out, the landed gentry, titled industrialists and financers had long been integrated with the aristocratic, priestly and bureaucratic strata, forming a Conservative 'power bloc'. ${ }^{113}$ Gerald Brennan remarked that there "was a long tradition among the Spanish governing classes of how to break a revolution. Indeed such arts contained for them the whole of politics." 114 The overthrow of the Spanish Republic was hardly a surprise, therefore. Only the fact that resistance provoked civil war indicated a long run-weakening of reaction. Left-wing resistance, however, was put to useful work by the conservative technicians of power led by the army, who had been long prepared by General Mola for "uncommonly violent" action "to bring down the enemy". Plans were ready-made for "exemplary punishments to stifle any rebellions or strike movements". ${ }^{115}$ The army rose against the left-wing Republican government in 1936 with the open support of landowners, employers, church and most police. The Spanish left had been acutely aware of the dangers of reaction, and the political parties, including the anarchists, organised militias to resist the technicians of power that crisscrossed the nation and rebelled against the regime. It was the counter-revolution that radicalised the revolution. In Republican territory, as Tim Rees writes, a "'red Terror' of revolutionary violence and destruction operated against rightists, the church and its clergy, fuelled both by the desire for revenge and also as a means to suppress counter-revolution."116 The Republican government checked this popular surge against reaction, but its own lack of military capability and experience could not in the end resist the Nationalist rebellion, even if its struggle was prolonged by support from Soviet Russia and the armed solidarity contingents of the International Brigades. An unbroken technocracy of power was proven to be nearly impregnable.

The real difficulty for the left in Europe at the end of the First World War was the dyed-in-the-wool hostility of the 'permanent state' - army, bureaucrats, police, judiciary, landlords, big-business - to democratisation. But this power technocracy could not be simply picked apart without running the risk of general dissolution and civil war. The technicians of power, moreover, were widely considered to represent the true nation, being above 'mere politics' and against divisive party divisions and left-wing cosmopolitanism. The radical 
right, meanwhile, ceaselessly undermined the legitimacy of democratic institutions. Rightwing extremists looked forward to a patriotic putsch "carried out with the collusion of high military and civil personalities, as the climax of a violent public agitation”, as Louis Ducloux, director of the Department of criminal investigation in the French Sûreté, put it. ${ }^{117}$ Fearing catastrophic collapse - painfully evident in the Russian experience - the left decided against confronting the power technocracy. Léon Blum, premier of the 1936 Popular Front government in France, proposed only a souffle républicain (a breath of Republican fresh air) to waft away reactionaries in the state administration. Even then, only a handful of senior civil servants were dismissed. ${ }^{118}$ Left in post in almost all countries and claiming the mantle of nationalist rectitude, these technicians of power went on to facilitate the inter-war model of dictatorship.

It was the same technicians of power, however, who collaborated with the German invaders and their allies during the Second World War. Outside the fanatical National Socialist ideologues, the typical collaborators in France were concentrated in what Stanley Hoffman calls the "social authorities", those comprising "the cream of the top of the civil service, of the armed forces, of the business community, of the social elites of landowners or the professions or the local notables." 119 This time they did not avoid a reckoning. As Germany crashed to defeat, the technicians of power in many countries were condemned as treacherous collaborators. They had definitively lost their protective colouring as doughty patriots. The power technocracy, moreover, could now be subjected to a far more thorough purge because of the frame of stability provided by the Allied armies. Because the Allies had demanded unconditional surrender rather than a 1918 style armistice, they pressed German militarism to complete destruction, and their armies of liberation occupied most of Europe. Societal dissolution and civil war was generally not a risk (with odd exceptions) because occupying armies and administrations held the ring. This permitted a far more thorough restructuring of the power technocracy than had been conceivable after the Great War.

The outcome was a massive revolutionary re-ordering in continental Europe from about 1944 to 1946 . This revolutionary purge of the technicians of power, unprecedented in scale and scope, took the form of popular Resistance-led persecutions as well as a more ordered series of trials, vettings, and demotions overseen by Liberation governments. It was a rough affair but, as Mark Mazower points out, "it was hard to imagine a genuine democracy flourishing anew without the punishment of its enemies". ${ }^{120}$ It is the case that most 
victims were guilty of collaboration (and most lost their comfortable jobs rather than their lives). ${ }^{121}$ By 'salami tactics', the Russian directed communist parties of Eastern Europe entirely extirpated the old technicians of power, importing émigrés and Soviet overseers to build a new governing apparatus from the ground up. Democracy was considered by the communists to be too great a risk. In contrast, the removal of pre-war officeholders from positions of power was seen as the necessary precondition for the consolidation of post-war democracy in Western Europe. This was Europe's 'Glorious Revolution' - a radical purging and reconstruction of the power technocracy under the protective cover of exogenous military and political direction.

Still, the great purge of the technicians of power was not entirely complete. The Cold War from 1947 allowed not a few collaborators or fascist eminences to remain in post, or to creep back in (often as expert advisors to emergent NATO, as they had experience fighting the Red Army on the eastern front). ${ }^{122}$ The purges at the end of the Second World War really was the key episode in Europe's democratic transformation, but there was to be a significant coda in the left radicalism of 1968, which targeted the 'gerontocracy': rule by the aged and compromised technicians of power from the era of the war. German big business was still dominated by those heavy industrial companies, Thyssen and Krupp, which had formed a plutocracy in the days of the Kaiser and the Third Reich. ${ }^{123}$ University academics, protected by tenure, were notoriously riddled by those who had kept their heads down during the Nazi years. "Beneath their academic robes, the darkness of a thousand years," the students chanted. ${ }^{124}$ Chancellor Adenauer had promoted Hans Glöbke to head of the chancellor's office and Theodor Oberländer to the cabinet despite their close involvement in shaping Nazi policies. ${ }^{125}$ Kurt Georg Kiesinger, the Christian Democrat Chancellor of West Germany from 1963 to 1969, had joined the Nazi Party in 1933 and propagandised for the regime during the war. ${ }^{126}$ General Adolf Heusinger briefly Hitler's Chief of General Staff during World War II, went on to serve as first Inspector General of West German Armed Forces and as chairman of the NATO military committee between 1961 and 1964. In France, Maurice Papon, a former Vichy official, prospered in post-war government as prefect of the Paris police and minister of budget under Valéry Giscard d'Estaing. He was bought to trial for crimes against humanity only in 1997-98. In Italy, similarly, could be found many connections of family and personnel between the Fascist and the Republican elites. ${ }^{127}$ 
The popular protests of ' 68 did not of itself refashion the technocracy of power, but it unquestionably turned a spotlight on the remaining elements of anti-democratic culture that marinated the technicians of power, and promoted a kind of purge by retirement, death, and replacement. In the backwash of ' 68 , the authoritarian regimes of Greece, Portugal and Spain collapsed. Reaction to democracy thereafter would take the form of neoliberal restructuring of economic policy-making, the stiffening of the EEC into the European Union, and a general autonomisation of the power technocracy, both public and private.

\section{Conclusion:}

I have attempted here to sketch an epoch of democratisation, resisted by reaction and punctuated by revolutionary struggles. The struggle in England in the $17^{\text {th }}$ century between Crown and Parliament was fought out to considerable extent on the terrain of the 'unacknowledged republic' of the nation's technicians of power. Generally the 'selfgoverning' gentry had a preference for the perceived status quo ante, and a decisive shift to constitutionalism was achieved only under the aegis of a foreign king and his army. The French Revolution was offered no such adventitious stability to remodel its technocracy of power, which underwent purge and re-purge with no definitive triumph for revolution ideals for over 100 years. In Europe, governmental bureaucracy and the army held fast against the revolutionary tide in 1848, and around it coalesced a conservative structure of political and social governance that persisted until the Great War. Communism in the years 1917 to c1919 launched a frontal attack upon the technicians of power, hoping to purge, intimidate and coopt them. European socialists in western and central Europe shied away from this catastrophic approach but paid a heavy price in doing so. Democracy wilted and often collapsed under the weight of a hostile technocracy of power.

Europe in the Second World War era, in some respects, recapitulated on a grander scale the Glorious Revolution. The old technocracy of power was radically purged and reconstituted under the authority of military occupation. The price of constitutionalist victory in England had been the bureaucratic stifling of Ireland as a potential site of catholic counterrevolution. After the Second World War, Eastern Europe was likewise suppressed by a communist authoritarianism fearful of the recuperative power of reaction in this traditionally conservative, socially repressive glacis. Ireland in 1921 and Eastern Europe in 1989, by 
which time the ideological, social and administrative bases of counter-revolution had been smashed by repression or delegitimised by collaboration, won through to democratic independence from their imperialist-revolutionary occupiers.

The very broad picture painted here seeks to highlight a number of theoretical points. First of all, revolutions are political: they are focused on the state. They certainly take impetus from and have profound effects on economics, class structure and cultural discourse. Revolutionary struggle, however, is primarily about changing the form of governance.

Secondly, the state should not be considered narrowly in exclusively cabinet terms. The technocracy of power is not a mere instrument of ministers or commissars in the capital city. It has a life of its own, it can give rise to reformist impulses, and it resists with great effectiveness those reforms perceived to be against the interests of its personnel and values.

Thirdly, the whip of reaction is crucial in understanding how revolution is inhibited or radicalised. Counter-revolution is never marginal to revolution, for even if it appears to be defeated the revolutionary works on the assumption that it incubates among the technicians of power, can recuperate and will strike back. When fear of counter-revolution finally dissipates, revolutionaries cease being revolutionary. If there is no reaction, there are no revolutionaries.

Fourthly, revolutions may be considered punctual points of heightened struggle within a broad parabola of transformation over lengthy periods of time. These struggles may be topdown or bottom-up, glorious or sordid, idealistic or calculating, or some combination. But they interact and form some kind of unity. Revolutions are not exceptions in history: they are the punctuations in the developing equilibria. 
${ }^{1}$ Marc Mulholland is a College Fellow and University Lecturer in the History Faculty at St Catherine's College, Oxford University. He may be contacted at marc.mulholland@stcatz.ox.ac.uk.

${ }^{2}$ Leon Trotsky, The history of the Russian revolution, trans. Max Eastman (Ann Arbor, MI, 1957), 276.

${ }^{3}$ Karl Marx, 'The class struggles in France' Marx and Engels, Selected works (Two Vols, London, 1942), II, 192.

${ }^{4}$ For a summary, see Michael S. Kimmel, Revolution: a sociological interpretation (Cambridge, 1990), chap. 3.

5 “Counter-revolution is revolution" says Peter Calvert, Revolution and counter-revolution (Buckingham, 1990), 18.

${ }^{6}$ Crane Brinton, The anatomy of revolution (New York, 1938, 1952, 1965), 199-200

${ }^{7}$ Charles Tilly, 'The analysis of a counter-revolution', History and theory, vol. 3, no. 1 (1963), 30-58, 56.

${ }^{8}$ Doug McAdam, Sidney Tarrow and Charles Tilly, 'Comparative perspectives on contentious politics' in Comparative politics: rationality, culture, and structure, Ed. Mark Irving Lichbach and Alan S. Zuckerman (Cambridge, 2009), 260-90. Clark McCauley and Sophia Moskalenko, Friction: how radicalization happens to them and us (Oxford, 2011). ${ }^{9}$ Arno J. Mayer, The furies: violence and terror in the French and Russian revolutions (Princeton, NJ, 2000), 120.

${ }^{10}$ Arno J. Mayer, Dynamics of counter-revolution in Europe, 1870-1956: an analytical framework (New York, 1971), 98.

${ }^{11}$ Jack A. Goldstone, Revolutions: a very short introduction (Oxford, 2014), 26, 30-1.

${ }^{12}$ Jack A. Goldstone, Revolution and rebellion in the early modern world (Berkeley, 1991), 432.

${ }^{13}$ Pace Hannah Arendt, Crises of the Republic: lying in politics, civil disobedience on violence, thoughts on politics, and revolution (New York, 1972), 206.

${ }^{14}$ The wider state tends to be seen in excessively abstract terms as a 'system' and a 'conduit' for structural and international pressures. Noel Parker, Revolutions and history (Cambridge, 1999), 73-75. The state machine, of course, comprises actual people with interests and points of view. 
${ }^{15}$ The Oxford English Dictionary defines the technician as "A person knowledgeable or skilled in the technicalities of a particular field; esp. an expert in the formal or practical aspect of an art, sometimes with implications of a corresponding lack of creativity." ${ }^{16}$ H, H. Gerth and C. Wright Mills, From Max Weber: essays in sociology (Oxford, 1946, 1958), 228-29.

${ }^{17}$ Theda Skocpol, 'Bringing the state back in: strategies of analysis in current research' in Peter B. Evans, Dietrich Rueschemeyer, Theda Skocpol (eds), Bringing the state back in (Cambridge, 1985), 28.

18 Theda Skocpol, States and social revolutions: a comparative analysis of France Russia, and China (Cambridge, 1979), 29-30, 286, 291-92.

${ }^{19}$ Michael Mann, The sources of social power: the rise of classes and nation-states, 17601914 (Cambridge, 1993, 2012), 59.

${ }^{20}$ Jeff Goodwin, 'State-centered approaches to social revolutions,' in Theorizing Revolutions, ed. John Foran (London, 1997), 15.

${ }^{21}$ Heinrich Von Sybel, History of the French revolution, trans. Walter C. Perry, vol. 1 (London: John Murray, 1867), 372.

22 John Briggs, Christopher Harrison, Angus McInnes and David Vincent, Crime and punishment in England: an introductory history (London, 1996), 54.

${ }^{23}$ G. E. Aylmer, The King's servants: the civil service of Charles I, 1625-1642 (New York: Columbia University Press, 1961), 7.

${ }^{24}$ J. O. Lindsay, 'Monarchy and administration: European practice' in the New Cambridge modern history: the old regime, 1713-63 (Cambridge, 1957), 153.

${ }^{25}$ Samuel F. Scott and Barry Rothaus, eds., Historical dictionary of the French Revolution 1789-1799, vol. 1 (Westport, CT, 1985), 521.

${ }^{26}$ Thomas Ertman, Birth of the leviathan: building states and regimes in medieval and early modern Europe (Cambridge, 1997).

${ }^{27}$ Walter Oppenheim, Europe and the enlightened despots (London, 1990), 50. Cf. Richard Bonney, The Limits of absolutism in ancien régime France (Aldershot, 1995) and Nicholas Henshall, The Myth of Absolutism: Change and Continuity in Early Modern European Monarchy (London, 1992).

${ }^{28}$ Eugene M Anderson and Pauline R Anderson, Political institutions and social change in continental Europe in the 19th century (Berkeley, 1967), 126. 
${ }^{29}$ H. H. Gerth and C. Wright Mills, From Max Weber: essays in sociology (Oxford, 1946, 1958), 229.

${ }^{30}$ Göran Therborn, What does the ruling class do when it rules? State apparatuses and state power under feudalism, capitalism and socialism (London, 1978), 75.

${ }^{31}$ Fritz K. Ringer, Education and Society in Modern Europe (London, 1979), 272, 316. 32 “... not only actual military and bureaucratic elements, but also the social strata from which, in the particular national structure, bureaucracy is traditionally recruited, must be included in such analyses." Antonio Gramsci, Selections from the prison notebooks, ed. and trans. Quinton Hoare and Geoffrey Nowell-Smith (London, 1971), 212.

33 "In the sense that the world became safer for economic expansion, backed by government, the term 'bourgeois revolution' has some validity.” Anne Hughes, 'The English Revolution of 1649' in David Parker (ed.), Revolutions and the revolutionary tradition in the West, 1560 - 1991 (London, 2000), 50.

${ }^{34}$ William H Sewell, 'Historical events as transformations of structures: inventing revolution at the Bastille' in Logics of history: social theory and social transformation (Chicago, 2005), 227.

${ }^{35}$ George Lawson, Negotiated revolutions: the Czech Republic, South Africa and Chile (Aldershot, 2005).

${ }^{36}$ William H Sewell, 'Historical events as transformations of structures,' 227.

${ }^{37}$ Perry Anderson, A zone of engagement (London, 1992), 44.

${ }^{38}$ Which themselves, of course, characteristically go through phases over number of years as has been pointed out since the 'natural history' school of revolution.

${ }^{39}$ The term, of course, borrows from Niles Eldredge and S. J. Gould, 'Punctuated equilibria: an alternative to phyletic gradualism' in T.J.M. Schopf (ed.), Models in paleobiology (San Francisco, 1972), 82-115. Cf. Philip Corrigan and Derek Sayer, The great arch: English state formation as cultural revolution (Oxford, 1985).

${ }^{40}$ As argued by Paul Pierson, 'Big, slow-moving, and... invisible: macro social process in the study of comparative politics', in James Mahoney and Dietrich Rueschemeyer (eds.), Comparative historical analysis in the social sciences (Cambridge, 2003), 278-9.

${ }^{41}$ Eric Selbin, Revolution, rebellion, resistance: the power of story (London, 2010).

${ }^{42}$ Trotsky's prediction that a Russian revolution would issue forth as a proletarian-socialist government under siege was both brilliant and accurate, but it was shared by no other Marxist 
or Socialist Revolutionary of stature. Reidar Larsson, Theories of revolution: from Marx to the first Russian revolution (Stockholm, 1970) 286-347.

${ }^{43}$ The classic short study is Irene Collins' Historical Association pamphlet, Revolutionaries in Europe, 1815-1848 (London, 1974).

${ }^{44}$ Excerpted in Thomas C. Mendenhall, Basil D. Henning, Archibald S. Foord, and Leonard Krieger, The quest for a principle of authority in Europe, 1715-present (New York, 1948), 95-6.

45 This is contrary to the view expressed by John Dunn that the French Revolution marks a break between political revolution and social revolution. See his Modern revolutions: an introduction to the analysis of a political phenomenon, second edition (Cambridge, 1972, 1989), 7.

${ }^{46}$ Laud was ultimately executed in 1645.

${ }^{47}$ Clive Holmes, Why was Charles I executed? (London, 2006), 43-45.

${ }^{48}$ Sir Charles Petrie, The letters, speeches and proclamations of King Charles I (London, 1935), 206.

${ }^{49}$ Blair Worden, The English civil wars, 1640-1660 (London, 2009), 42.

50 “The government had no real hold on the landed gentry ... Cromwell might well call out for new agents of his will.” D. W. Rannie, 'Cromwell's Major-Generals' in The English Historical Review, Vol. 10, No. 39 (Jul., 1895), 473.

${ }^{51}$ Steve Pincus, 1688: The first modern revolution (New Haven, 2009), 173.

${ }^{52}$ George Southcombe and Grant Tapsell, Restoration politics, religion and culture: Britain and Ireland, 1660 - 1714 (London 2010), 98, citing Mark Goldie, 'The unacknowledged republic: office-holding in early modern England,' in The politics of the excluded, c. 15001850, ed. Tim Harris (New York, 2001) 153-194.

${ }^{53}$ After James II fled London the population of the capital, fearing a descent of Irish soldiers in Royal pay, armed itself and attacked catholic property. This was long remembered as "Irish night". The pogrom, though it spread in succeeding days outside London, was repressed by the English soldiery.

54 The important and stimulating book by Steve Pincus on 1688 as 'the first modern revolution', f.n. 49, downplays the importance both of aristocratic unanimity and the protective covering provided by Dutch military forces in bringing about regime change, for fear of rendering the revolution less profound. In so doing, of course, he elevates the Glorious Revolution to the detriment of the English Civil Wars. Macaulay, in his consideration of both 
episodes as being on the same arc of development, his awareness that the concatenation of domestic opinion against James II must be fragile and temporary, and his belief that only the presence of William and his forces provided a breathing space for post-revolution construction, was perhaps more realistic in his evaluation of the Glorious Revolution. Lord Macaulay, 'Milton' (1825), 19-20, 'Hallam' (1828), 91, both in Macaulay's essays (London, 1886); The history of England from the accession of James II, five volumes (1849), II, 36163.

${ }^{55}$ Adrian Randall, Riotous assemblies: popular protest in Hanoverian England (Oxford, 2006), 20.

56 'Conclusion' in Philip T. Hoffman and Kathryn Norberg (eds), Fiscal crises, liberty, and representative government, 1450-1789 (Stanford, 1994), 306.

${ }^{57}$ R. W. Postgate, Revolutions from 1789 to 1906: documents selected and edited with notes and introductions (New York, 1920, 1962), 40.

${ }^{58}$ Gaetano Salvemini, The French revolution, 1788-1792, trans. I. M. Rawson (London, 1954), 252

59 'Proclamation of the Convention to the French People' (23 January 23, 1793) in Leo Gershoy (ed.), The era of the French revolution, 1789-1799: ten years that shook the world (New York, 1957), 154.

${ }^{60}$ Postgate, Revolutions, 43.

${ }^{61}$ Clarence Crane Brinton, The Jacobins: an essay in the new history (New York, 1930), 129.

${ }^{62}$ Howard G. Brown, Ending the French revolution: violence, justice, and repression from the Terror to Napoleon (Charlottesville, 2006), 69.

${ }^{63}$ François Furet, Revolutionary France, 1770-1880 (Oxford, 1988, 1992, 1995).

${ }^{64}$ Robert Gildea, Children of the revolution: the French, 1799 - 1914 (London, 2008), 107.

${ }^{65}$ Report from Yssingeaux (Haute-Loire) by M. Mollin, delegate of the Club of Clubs, 12 April 1848 in Roger Price (ed.), Documents of revolution: 1848 in France (London, 1975), 91.

${ }^{66}$ Roger Price, The French second republic: a social history (London, 1972), 262.

${ }^{67}$ Roger Price, The French second empire: an anatomy of political power (Cambridge, 2001), 112

${ }^{68}$ Alistair Horne, The French army and politics, 1870 - 1970 (London and Basingstoke, 1984), 17. 
${ }^{69}$ Charles Seignobos, A political history of Europe, since 1814, ed. S. M. Macvane (New York, 1900), 189.

${ }^{70}$ Quoted in James Laver, The age of optimism: manners and morals, 1848-1914 (London, 1966), 18.

${ }^{71}$ See comments by Ludwig von Löhner quoted in Josephine Goldmark, Pilgrims of '48 (New Haven, 1930), 148-9.

${ }^{72}$ Rudolph Stadelmann, Social and political history of the German 1848 revolution, trans. James G Chastain (Athens: Ohio, 1948, 1975), 149.

${ }^{73}$ Alexis de Tocqueville, On the state of society in France before the revolution of 1789; and on the causes which led to that event (London, 1856, 1888), 8.

${ }^{74}$ Hans-Ulrich Wehler, The German Empire, 1871-1918, trans. Kim Traynor (Leamington Spa, 1973, 1985), 118-37.

${ }^{75}$ Marx, 'The crisis and the counter-revolution' [1848], Marx-Engels Collected Works $(M E C W)$, vol. 7, 431.

${ }^{76}$ Auguste Blanqui, 'Avis au peuple (le toast de Londres),' Annuaire historique universel pour 1851 (Paris, 1851), 56.

${ }^{77}$ Marx, 'The civil war in France' [1871] in $M E C W$, vol. 22, p 330-2; Marx, 'Speech at anniversary banquet' [1871] in Marx and Engels, Writings on the Paris Commune, ed. Hal Draper (New York, 1971), 225.

${ }^{78}$ Cf. Anthony Brewer, Marxist theories of imperialism: a critical survey (London, 1980, 1990), 105.

${ }^{79}$ Engel to Bebel (24-26 October 1891) in Karl Marx and Frederick Engels, Selected correspondence, 1846-1895 (New York, 1942), 493.

${ }^{80}$ Rex A. Wade, The Russian revolution, 1917, $2^{\text {nd }}$ ed. (Cambridge, 2005), 64.

${ }^{81}$ Key to the suppression of 1905 had been 'punitive expeditions' by specially selected troops, "a form of state terror directed at the state's own citizens." Abraham Ascher, The revolution of 1905: Russia in disarray, two volumes (Stanford, Cal., 1988), II, 330.

${ }^{82}$ Lenin quoted in Leon Trotsky, The history of the Russian Revolution, trans. Max Eastman (Ann Arbor, 1957), 359.

${ }^{83}$ Minutes of the Bolshevik Central Committee [16 October 1917], excerpted in Mark Jones (ed.), Storming the heavens: voices of October (London, 1987), 66-69.

${ }^{84}$ John Shelton Curtiss (ed.), The Russian revolutions of 1917 (Princeton, 1957), 165. 
${ }^{85}$ N. Bukharin and E. Preobrazhensky, The ABC of Communism [1919], ed. E.H. Carr (London, 1969), 162-3, 311-12.

${ }^{86}$ Jane Degras (ed.), The Communist International, 1919-1943. Documents. Vol. 1, 19191922 (London, 1956), 2. Cf. 'Theses on bourgeois democracy and proletarian dictatorship adopted by the first Comintern congress' [14 March 1919], in ibid., 14.

87 'The New Communist Manifesto' (Appendix 2) in Raymond W. Postgate, The Bolshevik theory (London, 1920), 192.

${ }^{88}$ V. Obolensky-Osinsky, 'How we got control of the State Bank' (1918) in James Bunyan and H. H. Fisher, The Bolshevik revolution, 1917-1918: documents and materials (Stanford, Cal., 1934), 321-22.

${ }^{89}$ Carl Landauer, European socialism: a history of ideas and movements from the industrial revolution to Hitler's seizure of power (2 vols, Cambridge, 1959), I, 1133.

${ }^{90}$ Walter Consuelo Langsam and James Michael Eagan, Documents and readings in the history of Europe since 1918 (Chicago, 1939), 773

${ }^{91}$ Leon Trotsky, Terrorism and Communism [1920] (Michigan, 1961) 102.

${ }^{92}$ Ivan T. Berend, An economic history of twentieth-century Europe: economic regimes from laissez-faire to globalization (2006), 146.

${ }^{93}$ David Priestland, Stalinism and the politics of mobilization: ideas, power, and terror in inter-war Russia (New York: Oxford University Press, 2007), 415.

${ }^{94}$ Charles S. Maier, Recasting bourgeois Europe: stabilization in France, Germany, and Italy in the decade after World War I (Princeton, 1975), 136-37.

${ }^{95}$ Geoff Eley, 'What produces democracy? Revolutionary crises, popular politics and democratic gains in 20th-century Europe' in Mike Haynes and Jim Wolfreys (eds), History and revolution: refuting revisionism (London, 2007), 187.

${ }^{96}$ Julius Braunthal, In Search of the Millennium (London, 1945), 217-22.

${ }^{97}$ Charles A. Gulick, Austria from Habsburg to Hitler (Two volumes, Berkeley and Los Angeles, 1948) II, 1277.

${ }^{98}$ Helmut Heiber, The Weimar Republic, trans. W.E. Yuill (Oxford, 1966, 1993), 8.

${ }^{99}$ F.L. Carsten, Revolution in central Europe, 1918-1919 (Aldershot, 1972, 1988), 131.

${ }^{100}$ David Mitchell, 1919: red mirage (London, 1970), 168.

${ }^{101}$ Richard J Evans, The coming of the Third Reich (London, 2003), 100. 
${ }^{102}$ Karl Liebknecht, 'Confront the counter-revolution!', 15 December 1918, in All power to the councils! A documentary history of the German revolution of 1918 - 1919, ed. and trans. by Gabriel Kuhn (Oakland, 2012), 107.

${ }^{103}$ Rosa Luxemburg, 'What does the Spartacus League want?', 14 December 1918, in ibid., 101.

${ }^{104}$ Albert S Lindemann, The 'red years': European socialism versus Bolshevism, 1919 - 1921 (Berkeley, 1974), 39.

${ }^{105}$ Sefton Delmer, Weimar Germany: democracy on trial (London, 1972), 57.

${ }^{106}$ See Eberhard Kolb, The Weimar Republic, second edition, trans. S. Falla and R.J. Park (Abingdon, 2005), 154-5.

${ }^{107}$ F. L. Carsten, The Reichswehr and politics, 1919 to 1933 (London, 1966), 30.

${ }^{108}$ Landauer, European socialism, I, 850-51.

${ }^{109}$ Quoted in Julius Braunthal, History of the International, vol. 2, 1914-1943, trans. John Clark (London, 1963, 1967), 389.

${ }^{110}$ Arthur Mitchell, Revolutionary government in Ireland: Dail Eireann 1919-22 (Dublin, 1995), 336.

${ }^{111}$ Quoted in Gaetano Salvemini, The origins of Fascism in Italy (London, 1942, 1973), 5657.

112 Zara Steiner, The lights that failed: European international history 1919 - 1933 (Oxford, 2005), 332 .

113 Julián Casanova, The Spanish republic and civil war (Cambridge, 2010), 20.

${ }^{114}$ Gerald Brennan, The Spanish labyrinth: an account of the social and political background of the Spanish civil war (Cambridge, 1941, 1971), 291.

${ }^{115}$ Casanova, Spanish republic and civil war, 141.

116 Tim Rees, 'Battleground of the revolutionaries: the republic and the civil war in Spain, 1931 - 39' in Moira Donald and Tim Rees (eds), Reinterpreting revolution in 20th century Europe (London, 2001), 128.

${ }^{117}$ Louis Ducloux, From blackmail to treason: political crime and corruption in France, 1920-40, trans. Ronald Matthews (London, 1958), 227.

118 Julian Jackson, The popular front in France: defending democracy, 1934 - 38 (Cambridge, 1988), 152-54.

${ }^{119}$ Stanley Hoffman, 'Collaborationism in France,' in The Journal of Modern History, 40:3 (1968), 389. 
${ }^{120}$ Mark Mazower, Dark continent: Europe's 20th century (London, 1998), 233.

${ }^{121}$ István Deák, 'Introduction' in István Deák, Jan T. Gross, and Tony Judt (eds), The politics of retribution in Europe: World War II and its aftermath (Princeton, 2000), 4, 12. Military, political and journalistic collaborators were treated sternly, as were informers.

Collaborationist businessmen evaded justice most easily, at least in Western Europe. Keith Lowe, Savage continent: Europe in the aftermath of World War II (London, 2012), 157. ${ }^{122}$ See the article by a former State Department official, John H. Hertz, 'The fiasco of denazification in Germany', Political science quarterly, Vol. 64, No. 4 (December 1948), 569-594.

${ }^{123}$ Angi Rutter, 'Élites, estate and strata: class in West Germany since 1945' in Arthur Marwick (ed.), Class in the twentieth century (Brighton, 1986), 153.

${ }^{124}$ Norman Birnbaum, After progress: American social reform and European socialism in the twentieth century (Oxford, 2001), 185-6.

125 John W. Young, Cold War Europe, 1945-1991: a political history, 2nd ed. (London, 1996), 84 .

${ }^{126}$ Mark Kurlansky, 1968: the year that rocked the world (London, 2004), 144.

${ }^{127}$ Paul Ginsborg, Italy and its discontents, 1980-2001 (London, 2001), 40. 